\title{
谷戸の地形特性と土地利用特性に関する研究 \\ A STUDY ON TOPOGRAPHICAL CHARACTERISTIC AND LAND USE FEATURE IN “YATO”
}

\author{
三笠友洋*1, 重村 力*2, 田中貴宏*3, 山崎義人*4, 内平隆之*5 \\ Tomohiro MIKASA, Tsutomu SHIGEMURA, Takahiro TANAKA, \\ Yoshito YAMAZAKI and Takayuki UCHIHIRA
}

\begin{abstract}
The Yato is a landscape unit often seen in hilly zone of South Kanto area. This paper is to clarify topographic characteristics and land use features of Yato in Yokohama City, where numbers of Yato and certain preceding studies of Yato exists. Through the research by GIS and TPI method, statistical measurement and cluster analysis, we found below: 1. Average area of Yato is 4ha and the bottom is almost 1 ha that means very compact size of daily walkable environment. 2 . The slope angle distributes between $5^{\circ}-8^{\circ}\left(\right.$ av. $8.11^{\circ}$ ) that means not to steep angle good to farming and housing. 3. There are 2 types of Yato ; one is Normal type and the other is Koyato type. Normal type consists of housing at bottom and slope as forest. Koyato type consists of small housing area at bottom and farming fields at gentle slope.
\end{abstract}

Keywords : Yato, GIS, topography, Land use, Yokohama 谷戸, GIS, 地形, 土地利用, 横浜

1. はじめに

\section{1-1 谷戸研究の背景}

関東平野南部の丘陵地帯の「谷戸」注 1) と呼ばれる小さな沢は、 「丘陵地に馬蹄形に入り込むように平地が形成された地形」であ る。横浜市は、市域の大半が丘陵地であり河川の流域の上流側の 無数の支流に，おびただしい谷戸が存在する。筆者らの研究にお ける定義と測定では 4364 注 2)の「谷戸」が横浜市域にある。すで に概略の基礎単位を寸法的に明らかにし(既報 $1^{1}$ ))。さらに GIS を 用いて谷戸を同定する方法を開発提案している(既報 22$)$ )。谷戸は 斜面地の里山及び沢奥の水源と緩斜面の畑、平地の水田に加えて 地形に守られた居住地とが組み合わされた生産・生活環境の単位 であり、社会環境の単位でもある。近世から近代にかけて、多く は同族親族の少数の住宅群とそれを支える自然環境としてバラン スしてきた地形環境 344)5)であった。これらの「谷戸」は 1960 年 代の高度成長期以降宅地開発され、多くの「谷戸」が宅地化され た。既往研究によれば 1881〜1994 年の地形図の比較では約 33\%

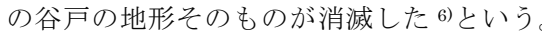

\section{1-2 本研究の対象と目的}

谷戸は南関東の丘陵地帯に多く存在する地形であるが、前述の
ように横浜市は全域にわたって谷戸が多く、また谷戸に関する優れ た既往研究があり、系統的に統計や各種の加工された地形図を追う 事ができる。本研究では基本的方法として横浜市域の「谷戸」の地 形特性を類型化しつつ、「谷戸」の現状での土地利用特性を明らかに し，これらを比較して谷戸の地形特性と土地利用の特性について明 らかにする。

横浜市環境科学研究所 7)が指摘するように、横浜市の土地利用の 変化を日本地図センター作成の図で見ると、1906 年と 1951 年の 45 年間を比較すると人口は概略で 36 万人から 100 万人と劇的に 3 倍 に増加しているのに、丘陵部の土地利用には劇的な変化は見られな い。増加人口の多くは港湾を中心とする沿岸部の市街地の拡大によ って吸収されたと見られるが、これらは現在の市域の大半を占める 西側の丘陵地には及んでいなかった。だがさらにその 43 年後の 1994 年の土地利用を見ると市街地の丘陵地部分の大半が市街地化 され、この間人口は 100 万人から 330 万人へとさらに 3 倍に増加し た。この増加部分は「谷戸」を含む丘陵地の開発によって吸収され たと考えられる。

別の見方をすると、日本で 2 番目の大きさの人口を擁する横浜市 は 1950 年代には 100 万都市の一つであり、人口は 1960 年代から 徐々に増加し 1970 年代から急速に増加し 1990 年代に 300 万に達
*1 神奈川大学工学部 助教・博士 (工学)

*2 神奈川大学工学部 教授・博士(工学)、 神戸大学 名誉教授

*3 広島大学大学院工学研究科 准教授・博士 (工学)

*4 兵庫県立大学大学院地域資源マネジメント研究科 准教授・博士 (工学)

* 5 兵庫県立大学環境人間学部 准教授・博士 (工学
Assist. Prof., Faculty of Engineering, Kanagawa Univ., Ph. D.

Prof., Faculty of Engineering, Kanagawa Univ., Ph. D.

Prof. Emeritus, Kobe Univ.

Assoc. Prof., Graduate School of Engineering, Hiroshima Univ., Ph. D.

Assoc. Prof., Graduate School of Regional Resource Management, Univ. of Hyogo, Ph. D.

Assoc. Prof., School of Human Science and Environment, Univ. of Hyogo, Ph. D. 
し、現在では 370 万を超えている ${ }^{8)}$ 。横浜市域は他都市のように 広大な低地や平地を有しているわけではなく、海岸べり及び河川 べりのわずかな狭い低地をのぞいては、大半はさほど高くはない 丘陵地であり、1960 年代からの人口増加はこの丘陵地の開発及び 宅地化に負うところが大きい。市街化されるにあたってこれら丘 陵地においては地形がどのように開発され、どのように保全され たのか?

丘陵地においては一部に公共セクター、大規模ディベロッパー による大規模開発が進行したが、複雑に谷戸の入り込んだ開発困 難な丘陵地形であるため、多くにおいては中小の開発主体による 小規模な開発が行われたほか、谷戸をまずは保全し、低地の平地 や台地上の平地を小規模に開発するなどの方法がとられたため、 $2 / 3$ の谷戸地形が残ったのだとも言える。

横浜市域を地形で区分すると、南東部の円海山(標高 $153 \mathrm{~m}$ )を 中心とする山地をのぞけば、浸食が進んだ高度 60 ～ $80 \mathrm{~m}$ の多摩丘 陵およびその下部の下末吉台地などの丘陵からなり、さらに谷底 低地、海岸平野、埋め立て地からなる注3)。

さきに述べた高度成長期以降の人口拡大にあたって市街化され た丘陵地は、この多摩丘陵から下末吉台地及び谷底低地が該当す る。「谷戸」は谷底低地と上部の台地丘陵との間に出来たおびただ しい数の浸食谷である。前述のように $1 / 3$ の谷戸が消滅し(開発さ れ)、逆に言えば $2 / 3$ の谷戸が残存された(保全された)のだが、そ の内容はどうであり、どのように近世から近代初期までの環境単 位であった谷戸は市街地に組み込まれたのか。この丘陵地帯の谷 戸に着目し、谷戸の地形はどのような特性を持ち、それらはどの ように開発されまたは保全され、今日の横浜市の市街地の相当数 の比率を占める丘陵近傍の住宅地をどのように形成しているの か? 谷戸の地形的特性と現沉の土地利用の関係について明らかに したい。

\section{1-3 本研究における解析の方法}

本研究では以下の方法をとる。第 1 に地名調查(既報 1 )からえ た谷戸の基礎単位の研究及び GIS から谷戸を同定する方法(既報 2 )をふまえて、横浜市域の全谷戸を抽出し、これを分析対象とす る。具体的にはまず DEM 注 4 )デー夕を基に GIS 上で TPI(Topographical Positioning Index) 注5)を算出し、谷底部に区 分されるセルを抽出する。次に GIS を用いて一次集水域を抽出し、 抽出された一次集水域の内、谷底部を含む区域を谷戸区域として 同定する注 6)。なお本研究では谷戸の各部位を以下の通り区分する (図 1、図 2)。「谷戸区域」の内、TPIにより谷底部と区分される 部分を「谷戸底部」とする。「谷戸区域」から「谷戸底部」を除い た斜面部および上部を「谷戸斜面部」とする。なお元になるデー 夕は、国土地理院刊行の「数值地図 $5 \mathrm{~m}$ メッシュ(標高)(横浜及川 崎 : 2009 年)」を用いる。

第 2 に谷戸の形状特性を、谷戸底部率、平均傾斜度、円周長比 の 3 つの地形指標を用いて分析する。個々の地形指標についてそ の平均值や頻度分布から谷戸の一般的形状特性を整理する。これ らの指標の数值にクラスター分析を試み、得られた地形類型の意 味を考察するとともに、地形図を例示してその特徵を見る。

第 3 に谷戸の土地利用特性について、「数值地図 5000 (土地利用)
(首都圈 2000 年)」を元データとして用いて、谷戸区域の土地利用構 成の特徴を見るとともに、市域全体および市域の非谷戸区域の土地 利用構成と比較する注7)。

第 4 に谷戸底部と谷戸斜面部における土地利用構成を比較考察す る。さらに上記の地形類型毎の土地利用特性の比較考察を行う。

これらから横浜市域の 4634 の谷戸の地形および土地利用特性を 明らかにする。

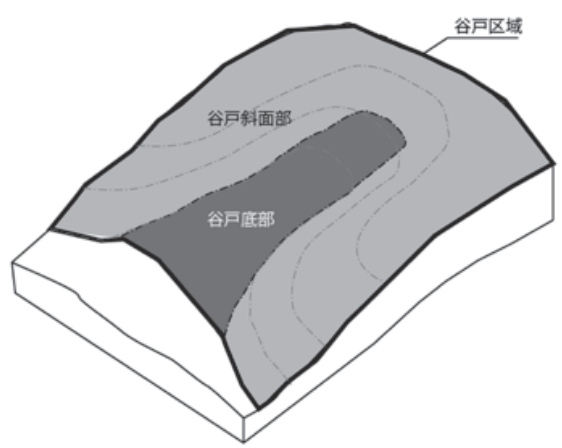

図 1 谷戸の地形部位の区分概念図

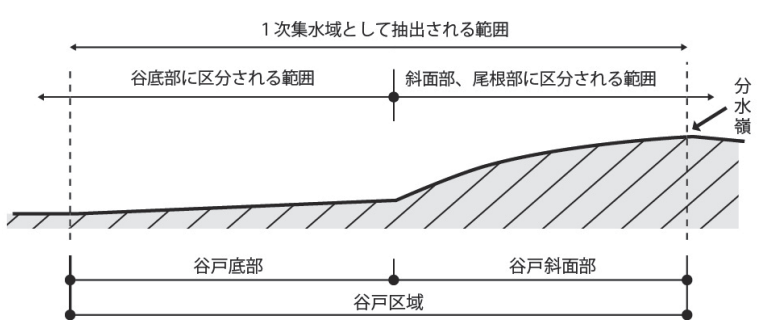

図 2 谷戸の地形部位の区分断面模式図

\section{1-4 地形指標}

本研究では用いる 3 つの地形指標の定義を以下に示す。

(1)谷戸底部率

筆者らの提案する谷戸底部率とは、「谷戸区域の全体面積に占める 谷戸底部面積の割合」であり、式(1)で算出する。

$$
\begin{aligned}
P=S_{b} / S_{a} \cdots \cdots(1) \\
P: \text { 谷戸底部率 } \\
S_{b}: \text { 谷戸底部面積 } \\
S_{a}: \text { 谷戸区域面積 }
\end{aligned}
$$

(2)平均傾斜度

平均傾斜度は各谷戸区域内にある全セルの傾斜度の平均值であり、 DEM から算出する。平均傾斜度が大きいほど、谷戸区域内に急傾 斜地点が多く起伏に富んだ地形であると言え、この指標により谷戸 の断面形状特性を比較することができる。傾斜度の大小は一般的に 造成等の開発コストを左右するため、土地利用への影響度が高い指 標と考えられる。

(3)円周長比

ここでは円周長比を、「谷戸底部を水平投影してできる図形の周長 を、同一面積の円の周長で割った值」と定義する。その值は式(2) で算出する。

$$
\begin{aligned}
R= & L_{b} / L_{0} \\
= & L_{b} / 2 \sqrt{\pi S_{b}} \cdot \cdots(2) \\
& R: \text { 円周長比 } \\
& L_{0}: \text { 基準円周長 } \\
& L_{b}: \text { 谷戸底部周長 }
\end{aligned}
$$


$S_{b}:$ 谷戸底部面積

谷戸は平地が丘陵に入り込んだ地形であり、その分析には谷戸 底部の細長さや入り組みの度合い等、その形状的複雑さに関する 指標が必要である。円周長比は、面積に対する周長が最小な最も 単純な形状である円を基準として図形の形状の複雑さを表した指 標といえる。図 3 は円周長比別に同一面積の図形を例示したもの である。谷戸底部の形状が純粋な円形であった場合円周長比は 1 となり、正方形の場合円周長比は 1.13 となる。細長いあるいは輪 郭が入り組んでいるなど形状が複雑になるほど円周長比は大きな 值を示す。

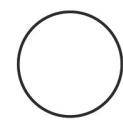

円周長比 $R=1$

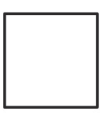

$\mathrm{R}=1.13$

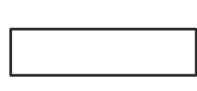

$\mathrm{R}=1.41$

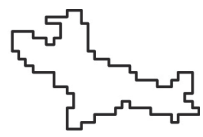

$\mathrm{R}=2.32$
図 3 同一面積の図形の形状による円周長比の違い

既報 1 によると谷戸底部の形状は間口が概ね $40 \mathrm{~m}$ から $60 \mathrm{~m}$ の 範囲に収まるのに対して、奥行は約 $200 \mathrm{~m}$ から $1300 \mathrm{~m}$ までばら つきがある。円周長比を指標として用いることで谷戸底部に見ら れるこうした形状の差異を分析に反映させる事ができれば、谷戸 の間口と奥行を測定することが不要となり、多数の谷戸をモデル 化する上で有効であると考えられる。

\section{2. 谷戸の地形特性}

\section{2-1 谷戸底部率}

図 4 は抽出された全 4634 カ所の谷戸について、谷戸底部と谷 戸区域の平均面積、平均谷戸底部率を示したものである。谷戸区 域面積の平均は 3.96ha であり、概ね $8 \mathrm{ha}$ 以下に分布している注 8 ) 谷戸底部面積は平均 $0.94 \mathrm{ha}$ で、概ね 0 〜 ha に分布している。谷 戸底部率の平均は 0.26 である。既報 2 で述べたとおり、樹林地(谷 戸斜面部)約 $3 \mathrm{ha}$ 、開墾地(谷戸底部) $1 \mathrm{ha}$ 強、谷戸底部率 0.25 程度 とする典型的谷戸の特徵と概ね近似している。谷戸底部率の頻度 分布を見ると、0.20～ 0.40 の区間に多く分布している（図 5）。

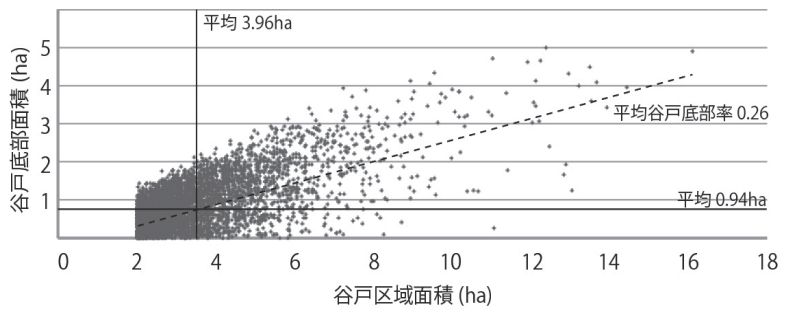

図 4 谷戸区域と谷戸底部の面積

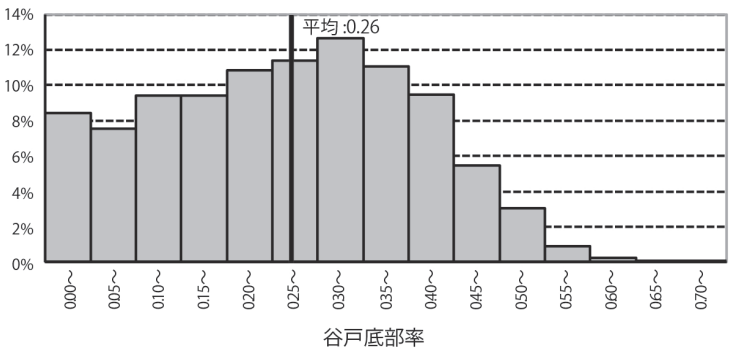

図 5 谷戸底部率の頻度分布

\section{2-2 平均傾斜度}

図 6 は 4364 力所の谷戸における平均傾斜度の頻度分布である。 全体の平均值は $8.11^{\circ}$ で、5 6 $6^{\circ}$ の区間で最も高い值を示している。 傾斜度 $0 \sim 15^{\circ}$ は緩斜面に分類され、その内、傾斜度 $3 \sim 8^{\circ}$ は、住 宅地として安全な傾斜度とされる注 9 )。また $8^{\circ}$ を超えると農地とし て土壌侵食防止の要が大きいとされる。谷戸の傾斜度は、総じて見 れば住宅地や農地として適当な緩やかな傾斜度であるといえる。

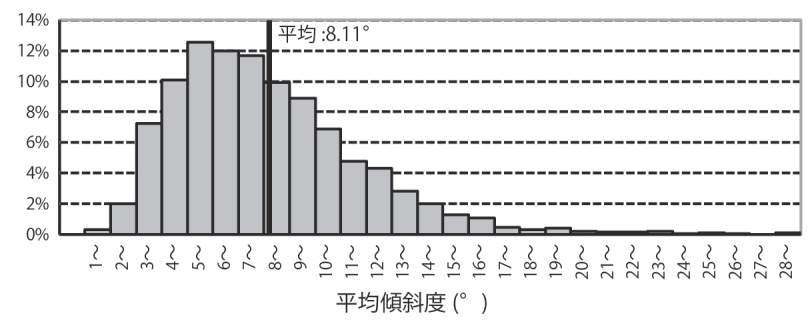

図 6 谷戸区域の平均傾斜角の頻度分布

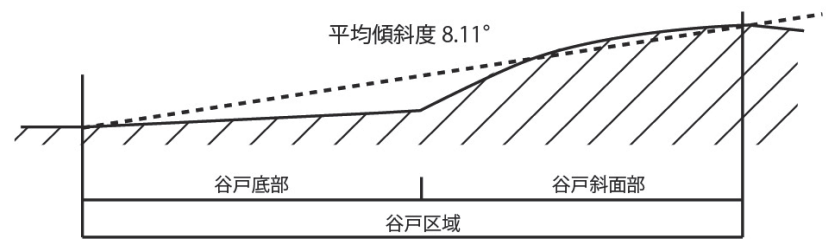

図 7 谷戸の平均傾斜度の断面模式図

\section{2-3 円周長比}

図 8 は全 4634 カ所の谷戸の円周長比の頻度分布を示したもので ある。平均值は 2.3 であり、全体の $90 \%$ が 1.4 〜 3.2 の範囲内にある。 円周長比の值に該当する谷戸底部の形状を図 9 に例示する。底部が 奥深く入り組む谷戸の特徴を表しており、そのばらつきは個々の谷 戸の特徴を表していると考えられる。

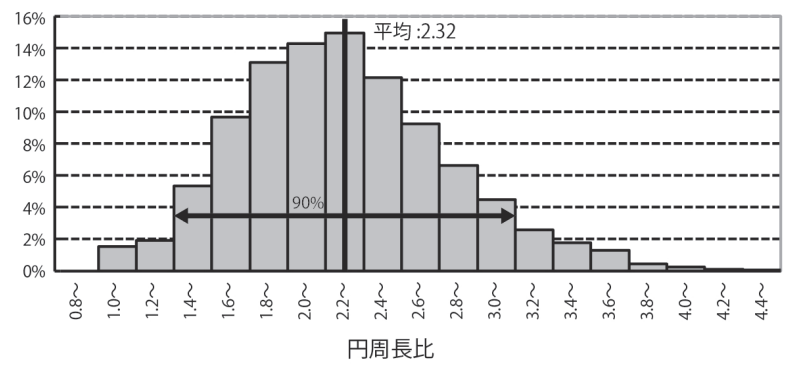

図 8 円周長比の頻度分布
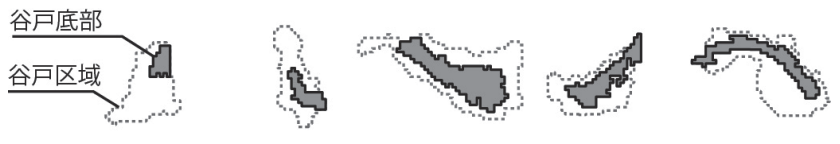

円周長比 : $R=1.4$

$\mathrm{R}=1.9$

$\mathrm{R}=2.3$

$\mathrm{R}=2.7$

$\mathrm{R}=3.2$

この指標と谷戸の間口奥行比との関係を確認するため、ランダム サンプリングした 233 の谷戸(全谷戸数の $5 \%$ )について、谷戸底部の 間口と奥行を測定した。測定した谷戸の谷戸底部の平均間口は $64.6 \mathrm{~m}$ 、平均奥行きは $205.3 \mathrm{~m}$ 、間口奥行比は 3.18 であり、既報 1 
で示した典型谷戸の形状特性と近い值を示している。間口奥行比 と円周長比の相関係数は 0.632 とやや強い正の相関を示した(表 1 、 図 10)。これより、円周長比を谷戸底部の間口奥行比をある程度 表す指標として用いうると考えられる。両指標の関係を示す近似 式は下記の通りである。

$\mathrm{D} / \mathrm{W}=3.5088 \times \mathrm{R}-3.5838 \cdots ・(3)$

$\mathrm{D}$ ：谷戸底部の奥行、 $\mathrm{W}$ ：谷戸底部の間口幅、 $\mathrm{R}$ ：円周長比 なお円周長比の平均值 2.3 を式(3)から間口奥行比に置き換えると 概ね 4.5 となる。既報 1 で示した谷戸の基礎的単位の間口奥行比 は 3.53(間口 $58.8 \mathrm{~m}$,奥行 $208.1 \mathrm{~m}$ ) であった。その值と比較すると やや大きな值を示しているものの概初近い值であり、間口の 3 〜 5 倍程度の奥行をもつ少し入り組んだ底部を有する基礎的な谷戸 の特徵を示していると考えられる。

表 1 谷戸底部の間口と奥行

\begin{tabular}{|r|r|r|r|r|r|}
\hline サンプル数 & $\begin{array}{c}\text { 平均間口幅 } \\
\mathrm{W}(\mathrm{m})\end{array}$ & $\begin{array}{c}\text { 平均奥行き } \\
\mathrm{D}(\mathrm{m})\end{array}$ & $\begin{array}{c}\text { 間口奥行比 } \\
\mathrm{D} / \mathrm{W}\end{array}$ & $\begin{array}{c}\text { 平均周長 } \\
\mathrm{L}(\mathrm{m})\end{array}$ & 平均円周長比 \\
\hline 233 & 64.6 & 205.3 & 3.18 & 841.7 & 2.32 \\
\hline
\end{tabular}

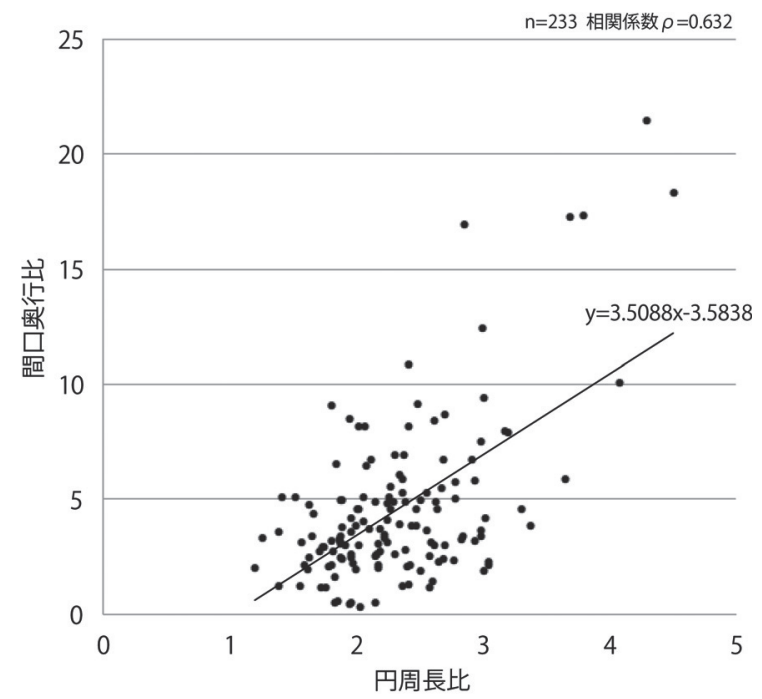

図 10 谷戸底部の円周長比と間口奥行比の関係

\section{3 つの指標による谷戸地形の類型化}

この 3 指標を用いて、ウォード法によるクラスター分析を行い、 全谷戸を 4 つの類型に分類した(表 2 )。事例数を見ると類型 1 及 び類型 2 がそれぞれ全体の約 $40 \%$ を占めており、また残る 2 つの 類型 3、類型 4 はそれぞれ全体の約 $10 \%$ 占めている。図 11 は 各類型に対応する谷戸を 2500 分の 1 の白地図に重ねて例示した ものである。3 指標の平均值から各類型の地形特性を見ていくと、 類型 1 は谷戸底部率がやや大きいが、平均傾斜度、円周長比のい ずれの指標も平均的な值で、標準的な谷戸類型(標準型) と言える。 類型 2 は谷戸底部率が際立って低く(全体の平均値の半分)、また 平均傾斜度も 4 つの類型の中で最も小さい。全体に緩斜面が多く 谷戸底部が小さい谷戸(小谷戸型)を示す類型と言える。類型 3 は 円周長比が突出しており、谷戸底部形状が入り組んだ谷戸(細長 型) と言える。類型 4 は平均傾斜角の值が突出しており、傾斜度の 大きい地点を多く含み全体として起伏の大きい谷戸(高起伏型)を
示す類型と言える。

表 2 クラスター分析による地形類型

\begin{tabular}{|l|r|r|r|r|}
\hline & 事例数(割合) & 谷戸底部率:平均 & 平均傾斜度 $\left(^{\circ}\right.$ ):平均 & 円周長比:平均 \\
\hline 類型1:標準型 & $1821(39.3 \%)$ & 0.35 & 9.1 & 2.2 \\
\hline 類型2:小谷戸型 & $1856(40.1 \%)$ & 0.13 & 5.3 & 2.1 \\
\hline 類型3:細長型 & $459(9.9 \%)$ & 0.26 & 7.2 & 3.4 \\
\hline 類型4:高起伏型 & $498(10.7 \%)$ & 0.44 & 15.5 & 2.3 \\
\hline 全体 & $4634(100 \%)$ & 0.26 & 8.1 & 2.3 \\
\hline
\end{tabular}

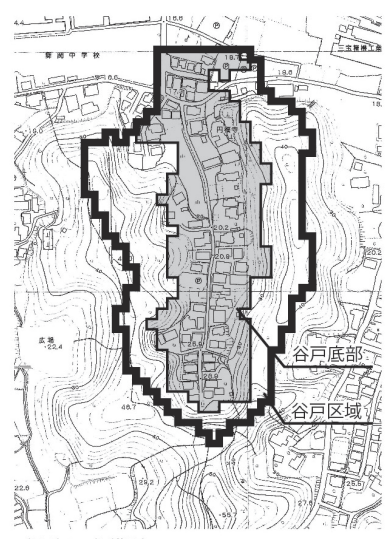

類型 $1:$ 標準型
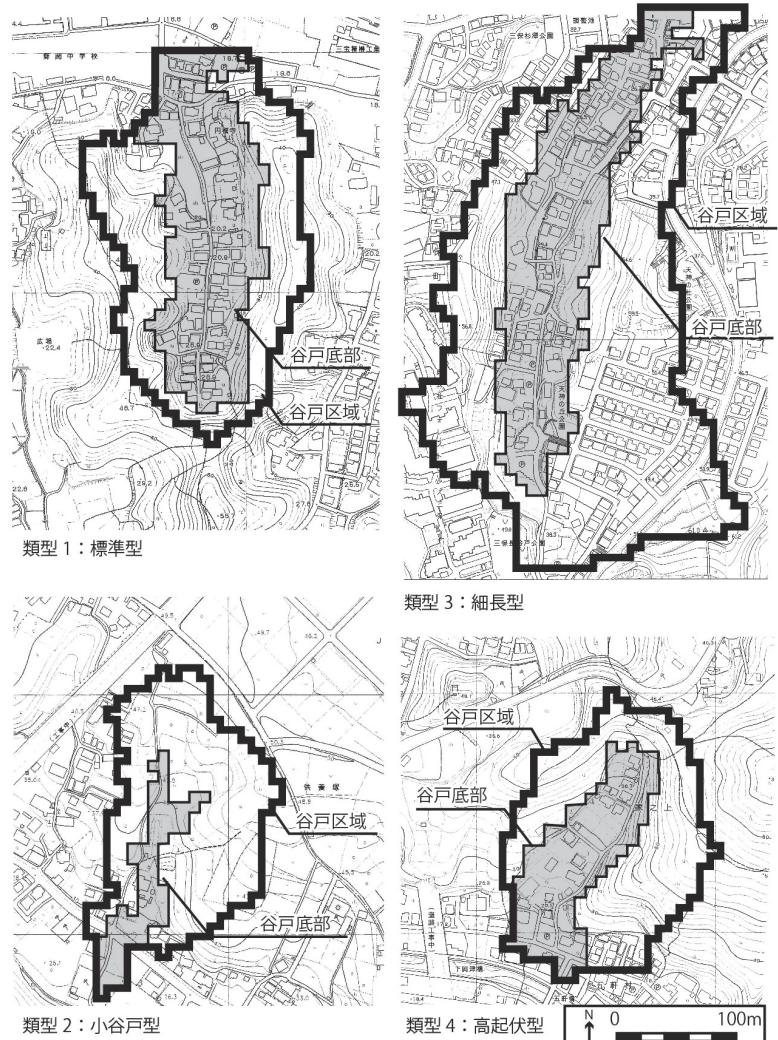

類型 $3:$ 細長型

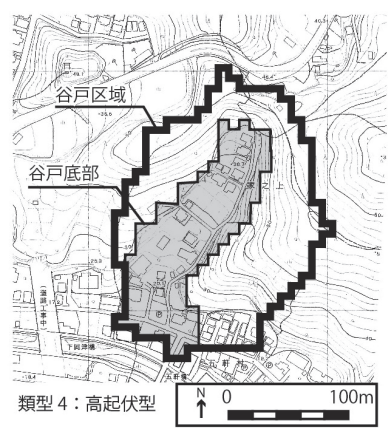

図 11 各類型に対応する事例

\section{4. 谷戸の土地利用特性}

\section{4-1 谷戸区域の一般的土地利用特性}

表 3 は谷戸区域と非谷戸区域の土地利用構成を比較し有意差検定 を行なったものである。谷戸区域の土地利用で最も大きな割合を占 めるのは住宅地である(36.6\%)。非谷戸区域では住宅地は $28.7 \%$ にす ぎない。谷戸区域に存在する住宅地の総面積は横浜全域の住宅地面 積の 4 割をしめており、谷戸が住宅地として寄与していることがわ かる。

有意差の見られなかった道路用地を除くと、次に大きな割合を占 めるのは山林である。谷戸区域では非谷戸区域に比べて山林が 2 倍 近い割合を占めている（谷戸区域：14.09\%、非谷戸区域 : 7.85\%)。 次に大きな割合を占めるのが農地である(谷戸区域： $8.99 \%$ 、非谷戸 区域： $8.13 \%)$ 。一般に大規模農地は平地に存在すると考えられる。 平地の占める割合が少ないにも関わらず農地が多いことから、谷戸 区域には平地型の大規模農地とは異なる小規模農地が多く保全され ている可能性があると考えられる。公園緑地の割合も非谷戸区域と 比べて大きく、谷戸が市街地における自然的環境の保全に寄与して いることが分かる。 
表 3 谷戸区域と谷戸区域外の土地利用構成

\begin{tabular}{|c|c|c|c|c|c|c|}
\hline 土地利用 & 谷戸 & 区域 & 谷戸区 & 或以外 & 横浜 & 域 \\
\hline & 面積(ha) & 割合 $(\%)$ & 面積(ha) & 割合(\%) & 面積(ha) & 割合(\%) \\
\hline 住宅地 & 6034.2 & $36.60 \%$ & 7601.2 & $28.70 \%$ & 13635.4 & $31.73 \%$ \\
\hline & 17.2 & & -17.2 & & & \\
\hline 山林·荒地 & 2322.8 & $14.09 \%$ & 2078.2 & $7.85 \%$ & 4401.0 & $10.24 \%$ \\
\hline & 20.7 & & -20.7 & & & \\
\hline 農地 & 1482.7 & $8.99 \%$ & 2152.3 & $8.13 \%$ & 3635.1 & $8.46 \%$ \\
\hline & 3.1 & & -3.1 & & & \\
\hline 空地 & 1112.3 & $6.75 \%$ & 1874.1 & $7.08 \%$ & 2986.3 & $6.95 \%$ \\
\hline & 1.3 & & -1.3 & & & \\
\hline 工業用地 & 210.5 & $1.28 \%$ & 1793.0 & $6.77 \%$ & 2003.4 & $4.66 \%$ \\
\hline & -26.3 & & 26.3 & & & \\
\hline 商業用地 & 755.6 & $4.58 \%$ & 2260.2 & $8.53 \%$ & 3015.8 & $7.02 \%$ \\
\hline & -15.6 & -15.6 & 15.6 & & & \\
\hline 道路用地 & 2400.3 & $14.56 \%$ & 3934.4 & $14.85 \%$ & 6334.7 & $14.74 \%$ \\
\hline & -0.8 & & 0.8 & & & \\
\hline 公園緑地 & 990.2 & $6.01 \%$ & 1327.0 & $5.01 \%$ & 2317.2 & $5.39 \%$ \\
\hline & 4.4 & & -4.4 & & & \\
\hline その他の公 & 1060.6 & $6.43 \%$ & 2472.8 & $9.34 \%$ & 3533.4 & $8.22 \%$ \\
\hline 共施設用地 & -10.7 & & 10.7 & & & \\
\hline 河川湖沼 & 43.9 & $0.27 \%$ & 615.1 & $2.32 \%$ & 658.9 & $1.53 \%$ \\
\hline & -16.9 & & 16.9 & & & \\
\hline その他 & 72.8 & $0.4 \%$ & 378.0 & $1.43 \%$ & 450.8 & $1.05 \%$ \\
\hline & -9.8 & & 9.8 & & & \\
\hline 合計 & 16486.0 & $100.0 \%$ & 26486.2 & $100.0 \%$ & 42972.2 & $100.0 \%$ \\
\hline 一有意に & 小もの & & 有意に & さいもの & & \\
\hline
\end{tabular}

$* \chi 2=1979, \mathrm{df}=10, \mathrm{p}<0.005$

$*$ 下段は調整済み標準化残差(太字はp<0.05)

\section{4-2 谷戸底部と谷戸斜面部の土地利用特性}

次に谷戸底部と谷戸斜面部の土地利用構成について比較した (表 4)。大きな差が見られるのは農地の割合である。谷戸斜面部で 農地の割合が大きく $(13.39 \%)$ 、谷戸底部の農地割合 $(7.4 \%)$ の 2 倍 近い值を示している。前節で示した谷戸の保全農地は谷戸斜面部 に多く存在すると考えられる。また住宅地の割合はやや谷戸斜面 部が多いが、大きな差はない。谷戸の伝統的土地利用では、谷戸 底部が谷戸斜面部の接する山裾に住宅が立地していたが、高度成 長期以降の宅地化によって、谷戸底部が宅地化した谷戸、谷戸斜 面部が宅地化した谷戸、まんべんなく宅地化した谷戸が併存して いる可能性が考えられる。筆者らの行なった谷戸の事例調查では、 これを裏付ける事例が確認されている(写真 $1,2,3)$ 。

\section{表 4 谷戸底部と谷戸斜面部の土地利用構成}

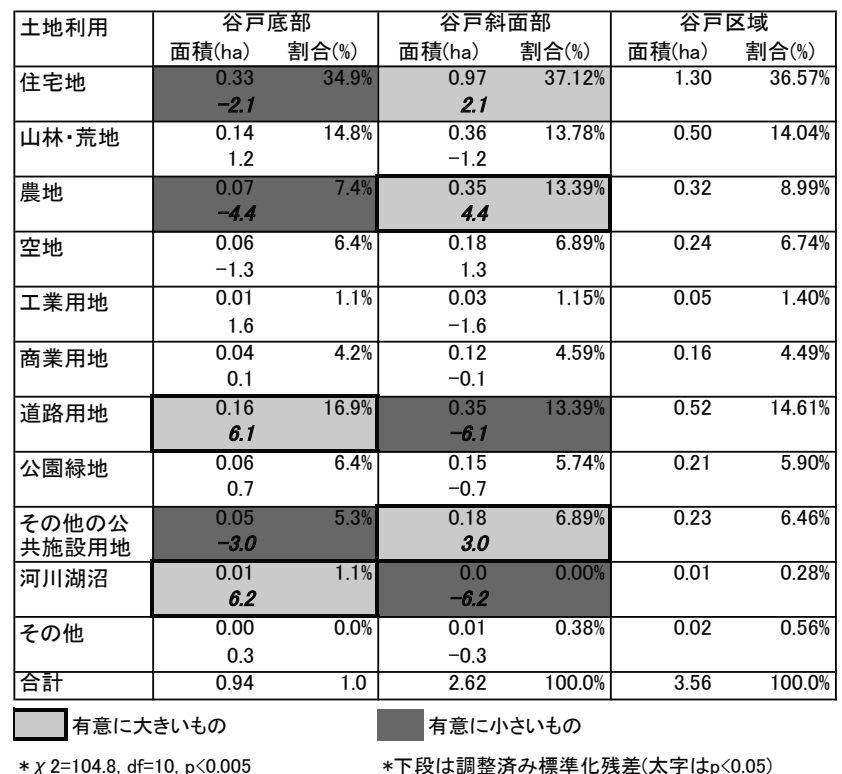

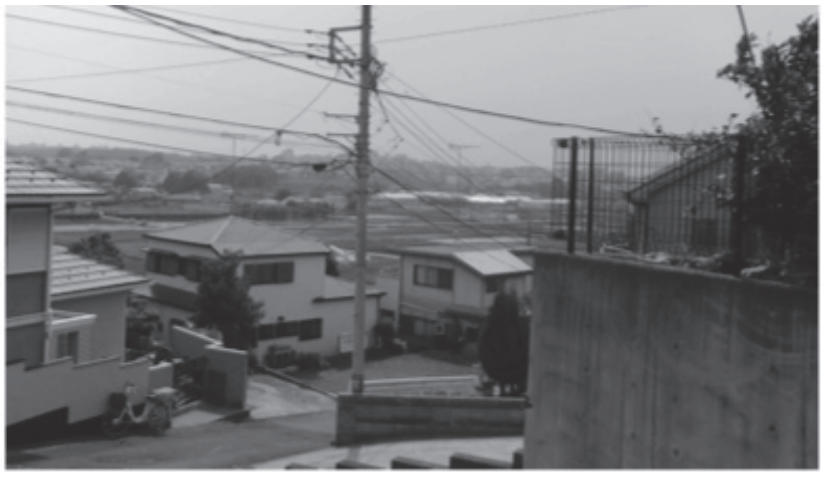

写真 1 谷戸斜面部宅地化、谷戸底部農地の事例 (緑区北八朔)

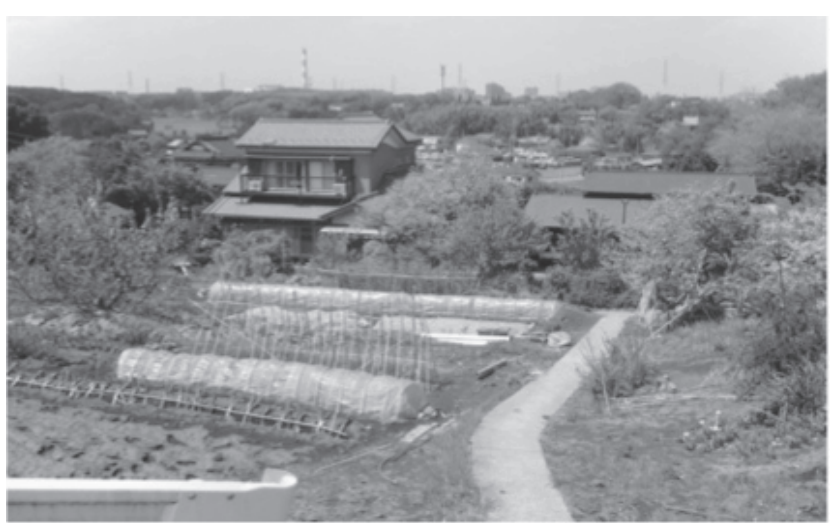

写真 2 谷戸底部宅地化、谷戸斜面部農地の事例 (都筑区折本町)

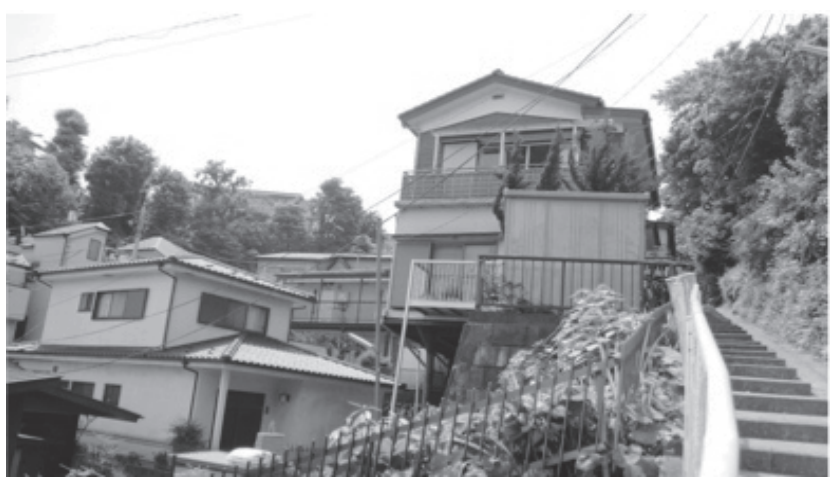

写真 3 底部斜面部共に宅地化した事例 (保土ヶ谷区西久保町)

\section{4-3 谷戸の地形類型別に見た土地利用特性}

次に前章で分類した谷戸の地形類型毎に土地利用特性を比較した (表 5)。まず類型 I の標準型は住宅地と山林の割合が大きく、逆に 農地の割合が小さい。谷戸斜面部の緑地を残しつつ、谷戸底部など の農地が住宅地化した土地利用構成とみることができる。標準型は 全谷戸数の約 $40 \%$ を占めており、現代の横浜市域における谷戸の 1 つの典型的土地利用を示していると言える。

類型 II の小谷戸型は、住宅地と農地、商業用地の割合が大きく、 逆に山林の割合が小さい。山林の割合は $5.8 \%$ ときわめて少なく、谷 戸区域全体の平均值の 2 分の 1 を下回っている。底部が小さく緩斜 面の多い小谷戸型は、他類型と比べ、谷戸斜面部が畑作などに利用 されやすいと考えられる。小谷戸型が全谷戸数の約 $40 \%$ を占める主 要類型であることをふまえると、前節で述べた谷戸斜面部の保全農 
地の多くは小谷戸型に存在していると推測できる。一方で住宅地 (38.5\%)、商業用地 $(5.7 \%) 、$ 公共施設用地 $(7.5 \%)$ の割合も他類型と 比較して大きい。つまり小谷戸型は農地保全に寄与している類型 であるといえるが、一方で住宅地、商業地やその他公共施設など に開発されやすい類型であると考えられる。

類型IIIの細長型は山林の割合が小さい(10.0\%)が、小谷戸型ほど ではなく、谷戸区域一般と大差なく、平均的な土地利用特性を持 つ類型であると言える。

類型IVの高起伏型では山林の割合が特に大きく、その割合は谷 戸区域一般(14.04\%)の 3 倍を上回る $42.8 \%$ に上る。公園緑地の割 合も大きい。一方で住宅地や商業用地の割合は小さい。高起伏型 は開発度が低いか、あるいは山林が保全又は公園として活用され る傾向があると考えられ、市街地における緑地保全に寄与寸る類 型であると考えられる。

表 5 地形類型別土地利用構成

\begin{tabular}{|c|c|c|c|c|c|c|c|c|c|c|}
\hline 土地利用 & 類型 I & $\begin{array}{l}\text { 標準型 } \\
\end{array}$ & 類型 II & 小谷戸型 & 類型吕 & $\begin{array}{l}\text { 細長型 } \\
\end{array}$ & 類型 $V^{\text {言 }}$ & 点起伏型 & 谷戸 & 区域 \\
\hline & $\begin{array}{l}\text { 平均面和 } \\
\text { (h) }\end{array}$ & 割合(\%) & $\begin{array}{c}\text { 平均面積 } \\
\text { (ha) }\end{array}$ & 割合(\%) & $\begin{array}{l}\text { 平均面積 } \\
\text { (ha) }\end{array}$ & 割合 $(\%)$ & \begin{tabular}{|l} 
平均面積 \\
(ha)
\end{tabular} & 割合 $(\%)$ & 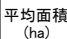 & 割合(\%) \\
\hline 住宅地 & $\begin{array}{r}1.32 \\
3.5\end{array}$ & $38.3 \%$ & $\begin{array}{r}1.27 \\
3.8\end{array}$ & $38.5 \%$ & $\begin{array}{r}1.98 \\
2.1\end{array}$ & $38.6 \%$ & \begin{tabular}{|r|r}
0.75 \\
-14.0
\end{tabular} & $21.4 \%$ & \begin{tabular}{|l}
1.30 \\
\end{tabular} & $36.57 \%$ \\
\hline 山林·荒地 & $\begin{array}{c}0.55 \\
5.4\end{array}$ & $16.0 \%$ & $\begin{array}{r}0.19 \\
-24.1\end{array}$ & $5.6 \%$ & $\begin{array}{l}0.51 \\
-6.2\end{array}$ & $10.0 \%$ & $\begin{array}{l}1.50 \\
36.4\end{array}$ & $42.8 \%$ & 0.50 & $14.04 \%$ \\
\hline 農地 & $\begin{array}{l}0.26 \\
-5.3\end{array}$ & & $\begin{array}{r}0.37 \\
8.1\end{array}$ & $11.4 \%$ & $\begin{array}{l}0.45 \\
-0.6\end{array}$ & $8.7 \%$ & \begin{tabular}{r|}
0.23 \\
-3.8
\end{tabular} & $6.5 \%$ & 0.32 & $8.99 \%$ \\
\hline 空地 & & & $\begin{array}{r}0.26 \\
4.7 \\
\end{array}$ & $7.9 \%$ & $\begin{array}{r}0.36 \\
0.6 \\
\end{array}$ & $7.0 \%$ & $\begin{array}{l}0.13 \\
-5.3 \\
\end{array}$ & $3.8 \%$ & 0.24 & $6.74 \%$ \\
\hline 工業用地 & $\begin{array}{r}0.04 \\
0.2\end{array}$ & $1.3 \%$ & $\begin{array}{r}0.05 \\
1.8\end{array}$ & $1.5 \%$ & $\begin{array}{l}0.06 \\
-0.5\end{array}$ & $1.2 \%$ & $\begin{array}{r}0.02 \\
-2.5\end{array}$ & $0.6 \%$ & 0.05 & $1.40 \%$ \\
\hline 商業用地 & & & $\begin{array}{r}0.19 \\
5.1 \\
\end{array}$ & $5.7 \%$ & $\begin{array}{r}0.25 \\
0.7 \\
\end{array}$ & $4.9 \%$ & $\begin{array}{l}0.06 \\
-6.0 \\
\end{array}$ & $1.7 \%$ & 0.16 & $4.49 \%$ \\
\hline 道路用地 & $\begin{array}{l}0.47 \\
-2.7\end{array}$ & $13.6 \%$ & $\begin{array}{r}0.53 \\
4.4\end{array}$ & $16.1 \%$ & $\begin{array}{r}0.88 \\
3.8\end{array}$ & $17.1 \%$ & $\begin{array}{l}0.31 \\
-7.1\end{array}$ & $8.9 \%$ & 0.52 & $14.61 \%$ \\
\hline 公園緑地 & $\begin{array}{r}0.21 \\
0.4\end{array}$ & $6.1 \%$ & $\begin{array}{l}0.17 \\
-3.1 \\
\end{array}$ & $5.3 \%$ & $\begin{array}{l}0.27 \\
-1.9 \\
\end{array}$ & $5.2 \%$ & $\begin{array}{r}0.33 \\
6.1\end{array}$ & $9.3 \%$ & 0.21 & $5.90 \%$ \\
\hline $\begin{array}{l}\text { その他の公 } \\
\text { 共施設用地 }\end{array}$ & $\begin{array}{l}0.21 \\
-1.7\end{array}$ & & $\begin{array}{r}0.25 \\
4.2\end{array}$ & $7.5 \%$ & $\begin{array}{r}0.35 \\
1.0\end{array}$ & $6.9 \%$ & $\begin{array}{l}0.13 \\
-5.1\end{array}$ & $3.6 \%$ & 0.23 & $6.46 \%$ \\
\hline 河川湖沼 & $\begin{array}{l}0.01 \\
-0.6\end{array}$ & & $\begin{array}{r}0.01 \\
0.7\end{array}$ & $0.3 \%$ & $\begin{array}{r}0.02 \\
0.3\end{array}$ & $0.3 \%$ & $\begin{array}{l}0.01 \\
-0.5\end{array}$ & $0.2 \%$ & 0.01 & $0.28 \%$ \\
\hline その他 & $\begin{array}{l}0.01 \\
-0.5\end{array}$ & $0.4 \%$ & $\begin{array}{l}0.01 \\
-2.2\end{array}$ & $0.3 \%$ & $\begin{array}{l}0.02 \\
-0.9\end{array}$ & & $\begin{array}{r}0.04 \\
5.2\end{array}$ & & 0.02 & $0.56 \%$ \\
\hline & 3.44 & & 3.30 & $00 \%$ & 5.13 & $0.0 \%$ & 3.50 & $0.0 \%$ & 3.56 & \\
\hline
\end{tabular}

有意に大きいもの 有意に小さいもの

$* \chi 2=1825 \mathrm{df}=30, \mathrm{p}<0.005 \quad *$ 下段は調整済み標準化残差 (太斜字体はp $<0.05)$

\section{5. まとめ}

本研究で明らかになったことを以下に列記する。

\section{1)地形特性について}

(1)谷戸区域の面積の平均は約 4 ha で、おおむ称 8 ha 以下に分布 し、谷戸底部の面積は平均 $0.94 \mathrm{ha}$ で、おおむ称 0 ～3ha に分布し ている。きわめてコンパクトな徒歩圈のサイズである。谷戸底部 率は $0.20 \sim 0.40$ に多く分布している。

(2)平均傾斜度は $5^{\circ} \sim 8^{\circ}$ の間に多く分布し、その平均は $8.11^{\circ}$ である。谷戸が緩やかな丘陵にさらに緩やかな斜面の開析谷を形 成している地形だと言うことを示している。この傾斜度は、ここ に緩やかな坂道をつくり、エロージョンの起きない範囲で宅地や 農地を立地させるのにふさわしい傾斜度といえる。

(3)谷戸底部形状の円周長比の平均は 2.32 である。円形は 1 、正方 形は $1.13 、 1: 5$ の長方形で 1.51 であるから、2.32 は相当に奥深い 形状であることを示し、この数值を間口奥行比に置き換えると概 叔 3〜 5 に相当する。

(4) 3 つの地形指標から、クラスター分析を行ない、標準型、小谷
戸型、細長型、高起伏型の 4 つの類型に谷戸を分類した。割合的に は標準型と小谷戸型がそれぞれ約 40\%を占めており、この 2 類型が 横浜市域における主要な谷戸類型と言える。

\section{2) 土地利用特性について}

(1)谷戸の土地利用で最も割合が大きいのは住宅地(36.6\%)であり、こ の值は非谷戸区域より約 $8 \%$ 大きい。横浜市の住宅地の約 4 割が谷 戸に存在しており、谷戸は住宅地としての役割を果たしている。 (2)谷戸は非谷戸と比べて山林、農地、公園の割合が多く、自然環境 の保全に寄与している。

(3)谷戸底部と谷戸斜面部を比較すると、谷戸斜面部の方が農地の割 合が大きい。住宅地の割合は大きな差がなく、谷戸底部が宅地化し た谷戸、谷戸斜面部が宅地化した谷戸、まんべんなく宅地化した谷 戸に分類される。

(4)標準型は谷戸底部に住宅があり、谷戸斜面部に樹林が残存してい る場合が多い。この標準型の谷戸によって里山が斜面地に残ってい ると言える。

(5)小谷戸型は谷戸底部に住宅があり、緩やかな斜面に農地を残寸場 合が多い。この小谷戸型によって都市内農地が残っていると言える。 (6)高起伏型は山林および公園緑地の割合が多い。この高起伏型は自 然環境の保全やその活用に役立っていると言える。

\section{謝辞}

本研究は、JSPS 科研費・基盤研究(B)「市街地における生活環境 資源としての『谷戸』の研究」（課題番号：22360255）の援助を受 けた。ここに記して学術振興会への謝意を表したい。

科研の研究グループには、本研究の発表者に加えて宇都宮大学/ 三橋伸夫、佐藤栄治、明治大学/川嶋雅章、神奈川大学/西和夫の諸 氏が加わっており、その助言によっていることを明らかにし、謝意 を表したい。

注

注1）本研究の対象とする谷戸地形を指す呼び名は地域によって異なり、「谷 戸」の他、「谷(ヤ)」「谷地(ヤチ)」「谷津(ヤツ)」など様々であるとされ るが、本研究では既報（文献 $4 、 5)$ と同様に「谷戸(十卜)」と称する事と する。

注2）既報 2 では抽出谷戸数を 4657 としている。これには谷戸底部面積がご く微小で 1 セル $\left(100 \mathrm{~m}^{2}\right)$ に満たない谷戸が含まれていたため、本研究で はそれらを除いた 4634 力所の谷戸を分析対象としている。

注3）参考文献 9 p.8 図 3 横浜市域の地形区分図=岡 1999 及び解説

注4) Digital Elevation Model(数值標高モデル) の略。対象地を格子状に区 切り、各セルに対し属性データとして標高值を保持させた形式のデータ

注5）TPI(Topographic Position Index)とは GIS を活用した地形解析の分野 で提案されている指標で、これにより地形区分が可能とされている。具 体的には DEM の各セルの標高値と、その周辺セルの標高平均值との差 で定義される。

注6）参考文献 2 参照。閾值として TPI-100、累積流量下限值 X-123 を用い ている。

注7) 本研究では、数值地図 5000 (土地利用)(首都圈 2000 年)」における 17 の土地利用分類の内、「海」と「対象地域外」を除いた 15 分類を基に、 下記の通り再編統合した 11 分類を用いている。

農地：「田」「畑・その他の農地」

空地：「造成中地」「「空地」

住宅地：「一般低層住宅地」「密集住宅地」「中・高層住宅地」

注8）谷戸区域面積の下限值 2 ha 付近にあるのは、既報 2 において 1 次集水域 
を抽出する際の集水流量の下限值の設定による。

注9）参考文献 10 による。P. 23 表「傾斜度による土地利用上の制約」にお いて傾斜度を 7 区分し、傾斜度と土地利用条件の関係を示している。 7 区分の内 $0 \sim 3^{\circ} 、 3 \sim 8^{\circ} 、 8 \sim 15^{\circ}$ の 3 区分を緩斜面としている。

\section{参考文献}

1）内平隆之・山崎義人 · 三笠友洋 - 田中貴宏・重村力：小字区域に着目し た谷戸の基礎的単位の抽出とその特徵-横浜市戸塚区旧川上村を事例に -, 日本建築学会計画系論文集, Vol.78, No.694, pp.2507-2511, 2013.12

2）田中貴宏・三笠友洋 - 内平隆之 ・山崎義人 ・ 重村力:GIS を活用した谷 戸の基礎単位の抽出とその現状に関する研究-横浜市を事例に -, 日本 建築学会計画系論文集，Vol.79, No.698, pp.933-938，2014.4

3）横浜市歴史博物館: 横浜市歴史博物館民俗調査報告第 1 集, 谷戸と暮ら し-戸塚区舞岡-, 1995

4）横浜市歷史博物館: 横浜市歷史博物館民俗調査報告第 2 集，谷戸と暮ら し-戸塚区名瀬-, 1996

5）重村力：上倉田・小串谷戸について, 市街地における生活環境としての 『谷戸』の研究, 谷戸研究会, pp.75-80,2014.3

6）森清和・島村雅英 : 横浜市域における谷戸地形の特質と推移に関する一 考察, 日本造園学会誌, Vol.64, No.5, pp.631-634, 2001.3

7）横浜市環境科学研究所 : 横浜型エコシティ研究報告「花鳥風月のまちづ $<り 」, 2002$

8）横浜市, 横浜市人口のあゆみ 2010 , 横浜市統計ポータルサイト, http://www.city.yokohama.lg.jp/ex/stat/jinko/ayumi/pdf/honbun.pdf, (参照 2014.12.10)

9）横浜市教育委員会・かながわ検定協議会編，わかるヨコハマ 自然・歴 史・社会，神奈川新聞社, 2009.6

10）建設省国土地理院：地域計画アトラス国土の現況とその歩み, 財団法 人日本地図センター, p23, 1984

11) Burrough, P. A., and McDonell, R. A., Principles of Geographical Information Systems (Oxford University Press, New York), 190 pp., 1998

12）藤原誠志・野原康弘・佐藤栄治・三橋伸夫 : 谷戸樹林地の管理活動の 実態-横浜市の谷戸樹林地に関する研究 1 -, 日本建築学会大会学術講演梗 概集，建築計画 II , pp.447-448，2011.7

13）野原 康弘・藤原 誠志 - 佐藤 栄治 - 三橋 伸夫 : 谷戸樹林地の管理と 保全に対する住民意識, 横浜市の谷戸樹林地に関する研究 2 , 日本建築 学会大会学術講演梗概集, 建築計画 II, pp.449-450, 2011.7

14）藤原誠志・佐々木成一・渡辺真季 - 三橋伸夫・佐藤栄治 : 谷戸樹林地 の保全施策と管理活動の変遷，横浜市の谷戸樹林地に関する研究 3 , 目 本建築学会大会学術講演梗概集, 農村計画, pp.1-2, 2012.9

15）川嶋雅章、港北ニュータウンを中心とした谷戸環境の変遷と現況緑環 境及び市民活動による維持管理, 市街地における生活環境としての『谷 戸』の研究, 谷戸研究会, pp.55-74, 2014.3

16）財団法人横浜市ふるさと歴史財団，開港 150 周年記念 横浜 歴史と 文化, 2009.6 


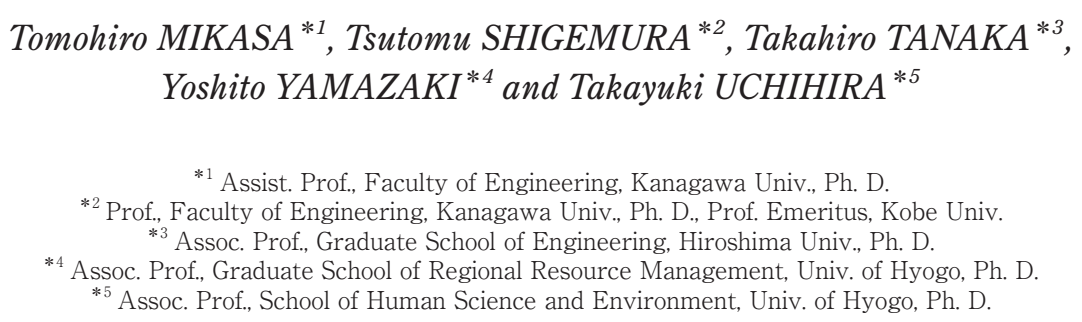

The Yato is a landscape unit where flat land takes the shape of a horseshoe, cutting into hilly areas. This research aims to clarify and classify the topographical characteristics of the current Yatos in the Yokohama region, while also clarifying the current state of the land use features of Yatos.

The research was conducted through the following methods:

First, we analyzed Yato's valley formation characteristics using three landform indices: the area ratio of Yato Yato bottom area, the average slope, and the perimeter length ratio. We ordered the general formal characteristics of the valley formations and then attempted a cluster analysis of the figures of these indices.

Second, we examined the characteristics of the land use composition in Yato areas, while comparing them to the land use composition of the entire city area, as well as the other areas within the city.

Third, we compared and investigated the land use features for each of the topographical types mentioned previously.

From the obtained results, the following conclusions can be drawn:

1) The average area of a Yato is 3.96 ha, while the average area of Yato bottom section is 0.94 ha. The average Yato bottom section ratio is distributed between $0.2-0.4$.

2) The average slope is $8.11^{\circ}$. This demonstrates that Yatos are suitable for the creation of gradually sloping paths, or the establishment of housing and agricultural areas in locations where erosion does not occur.

3) The average perimeter length ratio is 2.3. This indicates that the Yato bottom section forms a deep inset into the hills.

4) We conducted a cluster analysis using the three landform indices, and classified the Yatos into four types: i) Normal type, ii) Koyato type, iii) Deep depth type, and iv) Steep slope type. In terms of composition, the "Normal" and "Koyato" types each accounted for around $40 \%$ of the Yatos, making them the dominant Yato types in the Yokohama area.

5) The land in the Yato areas is primarily used for residential purposes, which comprises $36.6 \%$ of the land surface, and this figure is about $8 \%$ higher as compared to non-Yato areas.

6) Compared with the other area, the Yatos have a larger proportion of forested slopes, agricultural land, and parks, which all contributed to the protection of the natural environment.

7) A comparison of the Yato bottom section and inclined sections show that the latter held a larger proportion of agricultural land. There are no differences in the proportion of residential land.

8) Normal type consists of housing at bottom and slope as forest, and contributes to keep Satoyama in the city.

9) Koyato type consists of small housing area at bottom and farming fields at gentle slope. It contributes to keep farming field in the city.

10)Steep slope type there is a high proportion of forested slopes and green park areas. It contributes to conservation and utilization of natural environment in the city. 